\title{
KADROVSKI FORUM JAVNE UPRAVE 2003
}

GV Izobraževanje je 12. februarja 2003 organiziralo Kadrovski forum javne uprave 2003, ki je potekal v Ljubljani pod geslom Ključ do boljše uprave so ljudje.

Foruma se je udeležilo 129 kadrovskih delavcev in vodij iz 89 različnih organizacijskih enot.

Organizatorja je k pripravi tovrstnega foruma vodilo predvsem dejstvo, da nas le še dobro leto dni loči od trenutka, ko naj bi Slovenija postala polnopravna članica EU. In prav to dodatno prispeva $\mathrm{k}$ intenzivnosti sprememb v družbenem okolju nasploh, še zlasti pa v okolju javne uprave. Javna uprava je sredi reorganizacijskih procesov, posodablja procese upravljanja nalog in to prav v času, ko se obseg del povečuje predvsem na račun izvajanja nalog za potrebe EU. Pričakovanja in zahteve državljanov so vsak dan večji, vsi od državne uprave pričakujemo visoko strokovnost, učinkovitost in racionalnost. To je $v$ sleherni organizaciji, ne le v javni upravi moč doseči le s pomočjo zaposlenih - ljudi, ki imajo znanje, so motivirani, sposobni in nadarjeni, torej ljudi, ki znajo, hočejo in zmorejo.

Res je, da imajo tako organizacije kot tudi države različna zapisana pravila vedenja in ravnanja uslužbencev. Toda zgolj s postavljanjem pravil ne moremo doseči želene učinkovitosti. Veliko uspešnejši bomo, če bomo gradili in oblikovali praktične instrumente, postopke, modele in orodja za upravljanje s kadrovskimi viri.

Forum je odprl dr. Grega Virant, državni sekretar za javno upravo, ki je v uvodu poudaril, da je novi zakon o javnih uslužbencih le smernica za boljše upravljanje s ka- drovskimi viri $v$ javni upravi, sam po sebi pa seveda ne daje rezultatov; ti bodo mogoči šele s skupnimi prizadevanji vseh, ki se ukvarjajo s kadrovsko dejavnostjo. Prav tako je opozoril, da novega in presežnega zaposlovanja ne bo. Vsesplošno očitano dejstvo, da je v javni upravi preveč zaposlenih, skuša javna uprava reševati tako, da ne zapolnjuje več izpraznjenih delovnih mest $\mathrm{z}$ novimi zaposlitvami, temveč s pomočjo premestitve znotraj javne uprave.

$\mathrm{Na}$ forumu je sodelovalo 9 uglednih strokovnjakov iz javne uprave in zasebnega sektorja, ki tako ali drugače oblikujejo teorijo in prakso ravnanja $\mathrm{z}$ ljudmi pri delu $\mathrm{v}$ širšem slovenskem prostoru.

Dr. Grega Virant je pripravil analizo dosedanjega izvajanja zakona o javnih uslužbencih v praksi; opozoril je, da mora imeti vlada na področju upravljanja $s$ človeškimi viri predvsem izdelan kakovosten kadrovski načrt. Pri zasledovanju tega cilja se vladna kadrovska služba vse bolj preoblikuje $\mathrm{v}$ "strateški center za kadrovski menedžment", katerega naloga bo predvsem strateško kadrovsko načrtovanje, usmerjanje, svetovanje in zagotavljanje pomoči vsem, ki se bodo srečevali s kadrovskimi vprašanji. Zakon o javnih uslužbencih bo $\mathrm{z}$ uredbami in podzakonskimi akti prinesel dodano vrednost tudi na področju delovnih mest in nazivov. Po novem bo namreč mogoče na istem delovnem mestu napredovati $v$ višji naziv. Uredba o nazivih bo omejila vrste delovnih mest, ki jih bo po novem manj. Pray tako bo uredba prinesla splošne nazive delovnih mest, vsako delovno mesto pa bo omogočalo napredovanje v višsji naziv. Dr. Virant je opozoril tudi na 


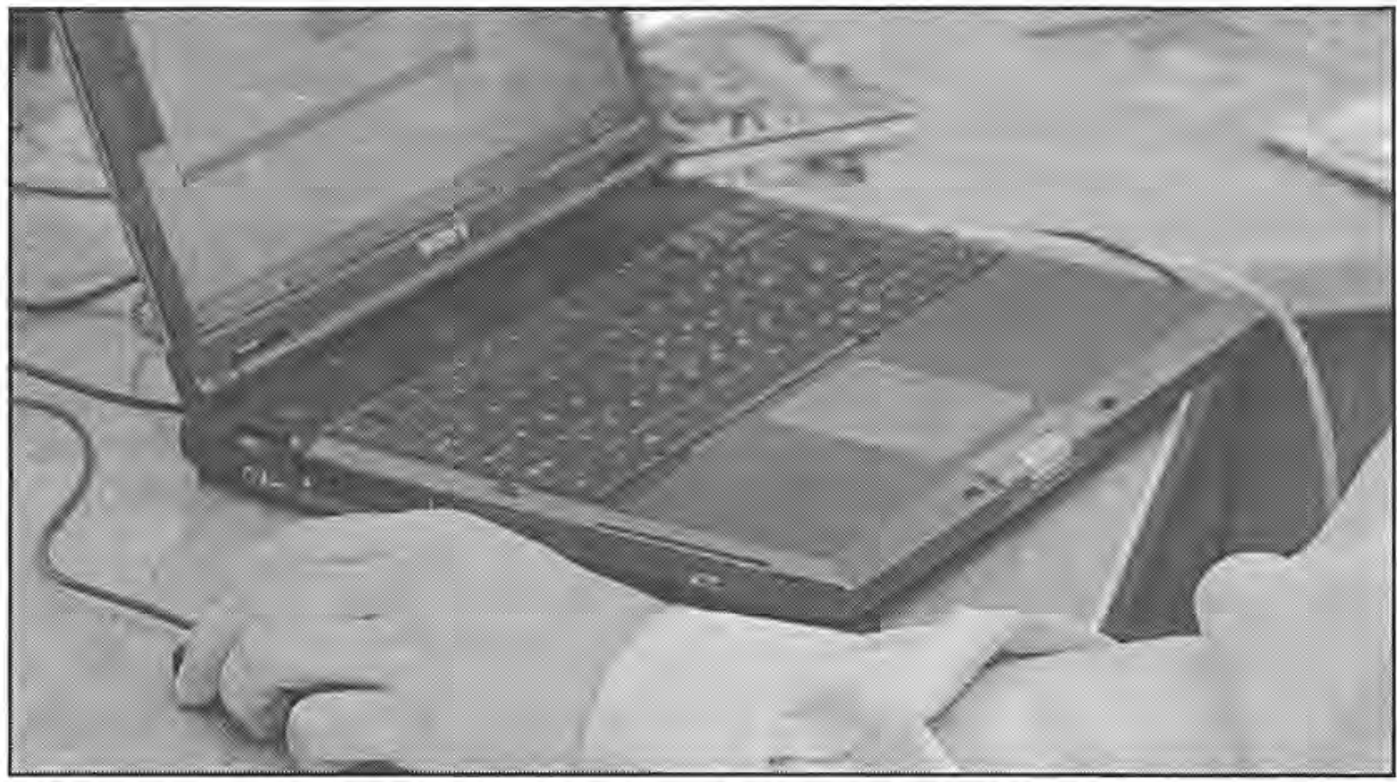

določena neskladja pri plačnih razmerjih in na potrebe po spremembah pri sistematizaciji delovnih mest. Ta bo morala biti po novem $v$ okviru kadrovskega in finančnega načrta, tako bomo resnično lahko racionalizirali delo javne uprave. Danes žal sistematizacija ne pomeni pravzaprav nič. Večji pomen bo pridobival "menedžment" javne uprave. V organizacijah zasebnega sektorja je več kot jasno, da je menedžer odgovoren za uspešnost oziroma neuspešnost podjetja. Zakaj potemtakem tako težko sprejemamo filozofijo vodenja in odgovornosti, ki se na to vežejo? Čakajo nas torej resne stvari, nov sistem javne uprave se bo namreč gradil na "top menedžmentu", kar se v javni upravi še ni zgodilo. Novi zakon o javnih uslužbencih daje torej le nastavke za model upravljanja s človeškimi viri, med drugimi uvaja tudi nekaj novih kategorij, kot je interni trg dela, projektno delo, ocenjevanje in napredovanje, za vsako delovno mesto bo treba pripraviti javni natečaj, prav tako pa zakon prinaša vrsto novih mehanizmov racionalizacije in ugotavljanja nesposobnosti.

Mag. Polona Kovač iz Urada za organizacijo in razvoj uprave je na forumu predstavila elemente upravljanja kadrovskih virov $\mathrm{v}$ evropskem modelu kakovosti $\mathrm{v}$ javni upravi - CAF. Evropski upravni prostor se vse bolj pomika od zgolj kadrovskega administriranja $\mathrm{k}$ upravljanju človeških virov. Zaposleni niso več uslužbenci, ampak viri, katerih potenciali so neomejeni, če znamo z njimi prav ravnati. In prav zato mora postati upravljanje s kadrovskimi viri del splošne strategije javne uprave. $\mathrm{V}$ ta namen se je razvil tudi skupni ocenjevalni okvir za organizacije $v$ javnem sektorju, bolj znan pod imenom CAF, ki upošteva specifičnost javne uprave. Specifičnost se kaže zlasti v tem, da v javni upravi še vedno vlada relativno nizka stopnja menedžerske avtonomije, nizka stopnja konkurenčnosti in manko optimalne stopnje virov. Na funkcionarskih mestih $\mathrm{v}$ javni upravi po polnopravni vključitvi v EU ne bo veljalo načelo prostega pretoka delovne sile, prav tako pa je javna uprava omejena pri zaposlovanju.

Ne glede na te specifičnosti tudi za javno upravo velja, da mora, če želi biti uspešna, graditi na proaktivnosti, avtonomiji in notranjem podjetništvu. $\mathrm{Z}$ namenom zasledovanja teh ciljev se je v Evropi razvil skupni ocenje- 
valni okvir za organizacije v javnem sektorju, ki je od 4. februarja 2002 na voljo tudi $v$ slovenskem jeziku. Model CAF upošteva specifičnost javne uprave, predvsem omejenost odločanja - politični vpliv, usmerjenost $\mathrm{k}$ strankam in procesom ter merjenje nefinančnih učinkov poslovanja. Namen CAF-a je identifikacija in opredelitev ključnih področij delovanja organizacije na tistih mestih, kjer so potrebne hitre izboljšave, Uvaja torej nujno potrebno samokritičnost in hkrati implicira opredelitev poslovnih procesov. Model CAF omogoča tudi kandidiranje za nagrado EFQM - nagrado za poslovno odličnost. Do danes za to nagrado ni kandidirala še nobena organizacija iz javnega sektorja. Ključna pogoja za uvajanje modela CAF sta nenehno inoviranje in učenje, torej učeča se javna uprava. Model CAF je vsekakor menedžersko orodje, ki vodi $\mathrm{k}$ stalnim izboljšavam in ima med drugimi tudi to prednost, da je primerljiv ne le $v$ slovenskem, ampak tudi $v$ evropskem prostoru. Je torej orodje za učenje in spreminjanje organizacijske klime, vse zaposlene vključuje $v$ procese izboljšav in hkrati pomeni razvoj skupnih vrednot ter nujno potrebno izmenjavo informacij in znanja.

Gospod Igor Klinar, direktor Urada za sistem plač v javnem sektorju, je na forumu predstavil Izvajanje zakona o sistemu plač v javnem sektorju v praksi. Poudaril je, da se danes zakon intenzivno izvaja predvsem $v$ delu, ki se ukvarja z določanjem osnovnih plač. Prikazal je pravne osnove in načine določanja osnovnih plač javnih uslužbencev, ravnateljev, direktorjev in tajnikov ter osnovnih plač funkcionarjev, Poudaril je, da predstavlja določitev osnovnih plač poleg preoblikovanega sistema ocenjevanja uspešnosti temelj novega plačnega sistema. Prehod na nov sistem pa dodatno upočasnjuje tudi stanje na področju javnih finane, kjer se pojavljajo določeni primanjkljaji na pri- hodkovni strani. Vsekakor bo potrebnih še kar nekaj usklajevanj, predvsem pa sprejetje kolektivne pogodbe za jāni sektor. Ob procesu usklajevanja plač ne smemo pozabiti tudi na istočasno informiranje o poteku in zaključkih tega procesa vseh zaposlenih $v$ javni upravi.

Gospe Mojca Fon Jager, dř̌avna podsekretarka na MNZ, in Mojea Babič, samostojna strokovna sodelavka na MNZ, sta nadgradili prejšnji prispevek s prispevkom Metodologija napredovanja oz. ocenjevanja delovne uspešnosti $v$ javnem sektorju. $V$ javni upravi se uvaja fleksibilna oblika nagrajevanja oziroma delitev plače na fiksni in variabilni del, pri čemer predstavlja variabilni del nagrado za uspešnost. Pri uvajanju kriterijev in meril za ocenjevanje delovne uspešnosti pa se $v$ javni upravi pojavlja problem merljivosti rezultatov dela, saj se javni uslužbenci ne soočajo z zunanjo konkurenco. Merjenje učinkovitosti je pomembno tako s stališča dobrega gospodarjenja javnega sektorja kakor tudi s stališča posameznika, ki tako prejme povratno informacijo o svojem delu in osebni učinkovitosti. V uradu za sistem plač so pripravili metodologijo za ocenjevanje delovne uspešnosti, ki upošteva tako zakonske podlage kakor tudi specifičnosti pri opravljanju del in nalog $v$ javni upravi.

$\mathrm{V}$ zakonu je določen skupen obseg sredstev za plačilo delovne uspešnosti, ki lahko znaša največ pet odstotkov letnih sredstev za osnovne plače. Tistim, ki so $\mathrm{z}$ racionalnim poslovanjem uspeli doseči prihranke oziroma so si del prihodkov pridobili neposredno $\mathrm{s}$ prodajo izdelkov in storitev na trgu, pa pripada delovna uspešnost $v$ višini največ ene plače.

Delovno uspešnost bodo ocenjevali neposredno nadrejeni. Ocenjevalo se bo vse javne uslužbence, in sicer po osmih kriterijih: rezultati dela, samostojnost pri delu, ustva- 
rjalnost, natančnost, zanesljivost, kakovost sodelovanja, organizacija dela in druge sposobnosti v zvezi z opravljanjem dela. Metodologija ocenjevanja delovne uspešnosti prinaša tudi opisne razlage pri posameznih merilih, kar prispeva $\mathrm{k}$ preglednosti ocenjevanja. $\mathrm{Z}$ merili morata biti seznanjena oba, tako ocenjevalec ko ocenjevani. Vsekakor drži, da je vsaka metodologija lahko le tako dobra, kot so dobri njeni kriteriji.

Namen metodologije je zagotoviti objektiven postopek ocenjevanja delovne uspešnosti in tako določiti nadpovprečne in podpovprečne posameznike, prav tako pa metodologija predstavlja tudi temelj za horizontalno napredovanje.

Gospod Radovan Kragelj je v svojem prispevku Psihološki vidiki vodenja za večjo učinkovitost $\mathrm{v}$ javni upravi $\mathrm{v}$ uvodu vsem udeležencem zastavil vprašanje: "Se kdaj sprašujete, zakaj uslužbenci $v$ javni upravi ne kažejo zanimanja za delo oz. jim je vseeno za rezultat? Ali so res takšni po naravi ali jih vodja ni uspel motivirati in navdušiti za delo?" Dober vodja mora biti predvsem psiholog, je poudaril gospod Kragelj, in pojasnil razlikovanje med vodjem in menedžerjem, med upravljanjem organizacij in vodenjem ljudi. Za obe vrsti dejavnosti so pomembne različne vrste sposobnosti in osebnostnih lastnosti. Za izboljšanje učinkovitosti je pomembna predvsem dejavnost vodenja. Za to dejavnost pa formalni vodje praviloma niso dovolj usposobljeni. V preteklosti je bila namreč praksa, da smo na položaje vodij delegirali tiste ljudi, ki so se izkazali pri določenem delu oziroma so bili najdlje $\mathrm{v}$ organizaciji. Velikokrat se je zgodilo, da smo na ta način dobili slabega vodjo in izgubili dobrega strokovnjaka. Vodenje namreč zahteva povsem drugačne sposobnosti in veščine kot opravljanje strokovnega dela. Še vedno pa je vodja s svojim stilom in kakovostjo vodenja glavni "krivec" uspešnosti oziroma neuspešnosti organizacije, zato bi morali veliko vlagati v področje izobraževanja za vodenje.

Brane Gruban, ugleden strokovnjak za področje razvoja človeških virov, je $v$ prispevku Motivacija in novi izzivi upravljanja delovne učinkovitosti $\vee$ javnem sektorju; razlike ali podobnosti $\mathrm{z}$ zasebnim sektorjem? opozoril na hitrost sprememb v poslovnem okolju, ki tako ali drugače vdirajo tudi $\mathrm{v}$ sektor javne uprave. Prav hitrost in intenzivnost sprememb $v$ zadnjem času sta povzročili pravo revolucijo iskanja novih načinov motiviranja ljudi in novih sistemov nagrajevanja, ki so tako postali stalen predmet interesa organizacij, zasebnih in javnih. Sistemski načini spodbujanja in motiviranja so preživeti, vse pomembnejšo vlogo dobiva individualna obrānnava zaposlenih in s tem unikatni načini motiviranja in nagrajevanja. Ti slonijo na sistemu kompetenc, pri čemer kompetence obsegajo znanje, veščine, spretnosti, vrednote, vedenja, motive, prepričanja in osebnostne lastnosti posameznika. Denar je le kratkotrajni motivator, motivacija mlajših generacij izvira iz njihovega sistema vrednot in privlačnosti delovnega mesta oz. vsebin dela. Pravzaprav je več podobnosti kot razlik $\mathrm{z}$ zasebnim sektorjem. Vsi tako ali drugače težimo k večji učinkovitosti.

Dr. Gozdana Miglič, vodja Uprảvne akademije, je na forumu predstavila temeljne Smernice razvoja upravljanja znanja na podlagi novosti, ki jih prinaša novi $\mathrm{ZJU}$. Učinkovit sistem izobraževanja in usposabljanja je temeljni pogoj za izboljšanje učinkovitosti javne uprave in uvajanja potrebnih sprememb. Vlaganje $v$ izobraževanje in usposabljanje mora predstavljati investicijo in ne strošek. Dejavnosti izobraževanja in usposabljanja morajo biti stalne, kar pomeni, da morajo biti skrbno načrtovane. V izvajanje strategije izobraževanja in usposabljanja naj 
bi bili vključeni vsi zaposleni. Pri tem je še zlasti pomembno, da jasno definiramo potrebe po izobraževanju. Č ugotovimo upad delovne učinkovitosti, namreč še ni nujno, da je razlog $v$ neznanju. Morda je treba razlog iskati $\mathrm{v}$ nerodno definiranih delovnih procesih, slabem vodenju ali zgolj nepripravljenosti posameznika za delo. Zatorej bo potrebno jasno definirati kataloge znanj, Novi Zakon o javnih uslužbencih zagotavlja odlično izhodišče za kakovostno upravljanje znanja $v$ javni upravi, saj določa tako pravice kot odgovornosti za izobraževanje slehernega zaposlenega. Ali bo dovolj, da se bomo javni uslužbenci na vseh ravneh zavedali odgovornosti za pridobivanje in vzdrževanje strokovnega znanja, se je za konec vprašala predavateljica.

Evropski model kakovosti v javni upravi CAF predvideva vrsto podpornih mehanizmov in eden izmed njih je tudi standard Vlagatelji v ljudi (Investors in people), ki ga je na forumu predstavil gospod Peter Beltram iz Andragoškega centra RS v prispevku Standardizacija ravnanja $\mathrm{z}$ ljudmi $\mathrm{v}$ javni upravi, predlog standarda Vlagatelji $\mathrm{v}$ ljudi. Sredi recesije v osemdesetih letih so $\mathrm{y}$ Veliki Britaniji uvedli standard Investors in people, $v$ slovenskem prevodu Vlagatelji v jjudi. V nekaj letih je standard doživel nesluten razmah in doživel neverjeten uspeh. Med nosilci naziva Vlagatelji $\vee$ ljudi pa so najbolje zastopana prav javna podjetja in javne službe, kar zagotovo priča o učinkovitosti tega standarda na področju ravnanja $\mathrm{z}$ ljudmi prav v javnem sektorju. Standard postavlja človeka $v$ središče uspešnosti organizacije, zagotavlja, da vsak zaposleni v organizaciji deli skupne cilje in vrednote, povečuje motivacijo in dosega višjo raven usposobljenosti. Največji učinki standarda so se pokazali na področju povečanja kakovosti storitev oz. izdelkov, povečanega zadovoljstva strank in učinkovitosti.
Odzivi udeležencev Kadrovskega foruma javne uprave 2003 so pokazali in opozorili na premajhno urejenost, skladnost in povezovanje različnih akterjev razvoja človeških virov v javni upravi. Opozorili so celo na določena neskladja zakona o javnih uslužbencih in zakona o plačah, ki zavirajo proaktivno delovanje na področju razvoja in posodabljanja področja človeških virov.

Prav tako se je pokazalo, da je nujno potrebno vzpostaviti takšen menedžment javne uprave, ki bo lahko učinkovito vodil ljudi v smeri načrtovane reorganizacije javne uprave. Pri tem dobivajo vodje precej drugačne zadolžitve in odgovornosti, ki se lahko $\mathrm{v}$ veliki meri primerjajo $\mathrm{z}$ vodenjem $\mathrm{v}$ zasebnem sektórju. Kot nujno potrebno se je pokazalo predvsem nenehno izobraževanje in usposabljanje zlasti vodij za učinkovito vodenje in delo $\mathrm{z}$ ljudmi.

Menim, da je bilo druženje na Kadrovskem forumu javne uprave 2003 nadvse koristno in potrebno, saj so lahko udeleženci preverili svoje strateške pristope $\mathrm{k}$ upravljanju kadrovskih virov in si naredili osebno analizo ukrepov in izboljšav, ki bi jih kazalo čimprej realizirati v praksi. Gibčnost in fleksibilnost javne uprave je namreč odvisna predvsem od pripravljenosti za učenje in aktivno delovanje $v$ smeri postavljene vizije $-v$ tem hipu sta to zagotovo večja učinkovitost in strokovnost, ki se lahko pohvalita še $z$ državljanom prijaznima. Prav zato bi si želeli, da postane tovrstno izobraževalno srečanje tradicionalno.
Mag. Daniela Brečko 